\title{
Nuevas estructuras tipo "sandwich" configuradas a partir de tejidos tridimensionales
}

\author{
New "sandwich" structures conformed from three \\ dimensional fabrics
}

JUAN J. ALBA, MIGUEL A. JIMÉNEZ, A. MIRAVETE ICMA-Dpto. de Ingeniería Mecánica de Zaragoza

\section{RESUMEN}

Las pobres propiedades, tanto interlaminares como de adhesión entre piel y núcleo, constituyen uno de los grandes problemas cuando se diseñan estructuras utilizando paneles tipo "sandwich". Un nuevo tipo de panel "sandwich", configurado a partir de tejidos tridimensionales, está siendo desarrollado en la actualidad con el objetivo de eliminar esos problemas. Aunque el proceso de fabricación es muy simple, el panel "sandwich" obtenido es de estructura compleja, como resultado de la complejidad del tejido tridimensional utilizado. Este tejido tridimensional (3D) es un tejido de fibra de vidrio producido en máquinas de tejer especializadas. La resistencia de las fibras verticales hace que, después de la impregnación con una resina, se mantenga la configuración tipo "sandwich". El resultado es un laminado de alta resistencia, gran rigidez y bajo peso. Sobre cada uno de los lados del panel "sandwich" se pueden laminar otros materiales de refuerzo, a la vez que se puede inyectar una espuma sintética en el hueco existente entre las pieles del "sandwich". Esto permitirá establecer las propiedades mecánicas finales del producto acabado.

\begin{abstract}
SUMMARY
Poor interlaminar properties as well as poor-skin-to-core adhesion properties are very often the common existing problems we find when designing with "sandwich" structures. A new type of 3D-fabric "sandwich" structure is being developed in order to avoid these problems. Although the manufacturing process is very simple, a very complex "sandwich" structure is obtained as a result of the complexity of the 3D-fabric used. This 3D-fabric is a 3D woven glass fabric produced on velvet weaving machines with glass yarns. It is an integrally woven "sandwich" laminate for all kinds of composite products. The strength of the vertical fibers makes, that also after impregnation with a resin matrix, the "sandwich" structure is maintained. The result is a laminate with high strength and stiffness and low weight. On each side of this "sandwich" laminate additional reinforcement materials can be laminated and a synthetic foam can be injected in the hollow structure. This will allow to establish the mechanical properties of a finished product.
\end{abstract}

\section{INTRODUCCIÓN}

Los tejidos estructurales representan la base de una clase de materiales compuestos avanzados utilizados generalmente para aplicaciones de alto compromiso estructural. Estos tejidos se caracterizan

fundamentalmente por ser preformas que servirán como refuerzo del diseño final de la estructura y han sido reconocidos desde hace muchos años por su ligereza, flexibilidad, resistencia y dureza. Las primeras aplicaciones de los tejidos estructurales se pueden situar entre la década de los veinte, cuando la compañía "Boeing Aircraft $\mathrm{Co}^{\circ}$. decidió utilizarlos para la fabricación de alas de avión, y finales de los años cincuenta, en el desarrollo de cabezas para los "missiles" y cohetes fabricados por "General Electric". La necesidad

\section{INTRODUCTION}

The structural fabrics represent the basis of a sort of advanced composite materials that are usually used in applications with high structural requirement. These fabrics are basically characterised by being preforms that will serve as reinforcement in the final design of the structure and have been from many years ago distinguished due to their lightness, flexibility, strength and hardness. The first applications of the structural fabrics can be situated between the twenties decade, when the "Boeing Aircraft $\mathrm{Co}^{\circ}$. decided to use them in the manufacturing of wings of planes, and the late fifties, with the development of the heads of "missiles" and rockets that were manufactured by "General Electric". The need of improving the intralaminar and 
de mejorar las resistencias intralaminar e interlaminar, así como la tolerancia al daño, de los materiales compuestos convencionales para aplicaciones actuales y futuras nos ha llevado a que durante las últimas décadas hayamos asistido a un importante resurgir de este tipo de materiales.

\section{PROBLEMÁTICA EXISTENTE CON LOS PANELES "SANDWICH' CONVENCIONALES Y MODIFICACIONES EXISTENTES}

El diseño de estructuras mediante la utilización de paneles "sandwich" nos enfrenta ante una serie de problemas comunes bien conocidos. De entre todos estos problemas destacaremos tres de ellos como los más relevantes: el problema de la delaminación, el fenómeno de las concentraciones de tensiones que se producen en torno a agujeros y uniones atornilladas y, por último, el problema de la resistencia al fuego. Para todos ellos se estudian de forma incesante posibles modificaciones, que pueden ser realizadas sobre los paneles "sandwich" convencionales, de modo que puedan reducirse los efectos perjudiciales para la estructura que se desee diseñar.

A continuación detallaremos brevemente estos tres problemas y algunas de las modificaciones propuestas.

\subsection{Delaminación}

El fenómeno de la tendencia a la delaminación en paneles "sandwich" se puede definir como la tendencia a que se produzca una rotura, debida a esfuerzos cortantes, de la unión existente entre el núcleo y las pieles.

Para evitar en la medida de lo posible que aparezca este fenómeno de delaminación, se intenta que la conexión entre pieles y núcleo sea lo más consistente posible para que de esta forma se produzca un mejor reparto de esfuerzos entre ambos componentes del "sandwich" y la rigidez del mismo no se vea afectada. La solución a este problema pasa generalmente por la utilización de capas de adhesivos endurecidos, situadas entre las pieles y el núcleo, que confieran mayores propiedades mecánicas a la unión entre ambos elementos.

Otro tipo de solución de cara a aumentar la resistencia del "sandwich" ante el fenómeno de la delaminación consiste en introducir algunas láminas menos rígidas dentro del laminado destinado a realizar las funciones de piel. Esta alternativa hará que aumente la tendencia del "sandwich" a la delaminación porque se facilita el deslizamiento entre las láminas más rígidas y las menos rígidas, pero la resistencia a la fractura debida a este fenómeno mejorará. De cualquier modo las propiedades interlaminar strength, and the damage tolerance, of the conventional composite materials for present and future applications has be the reason during the last decades for an important resurgence of this kind of materials.

\section{PROBLEMATIC OF CONVENTIONAL "SANDWICH" PANELS AND EXISTENT MODIFICATIONS}

The structural design by using "sandwich" panels make us to face a series of well know common problems. From all these problems three of them can be remarked as the most relevant ones: the delamination problem, the phenomenon of stresses concentrations around holes and bolted joints and, finally, the fire resistance problem. Possible modifications are incessantly studied to overcome these problems in conventional" sandwich" panels, modifications that should allow the reduction of the harmful effects over the structure that would be being designed.

Next, these three problems are briefly detailed and some of the proposed modifications.

\subsection{Delamination}

The phenomenon of the tendency to delamination in "sandwich" panels can be defined as the tendency to failure of the joint between the skins and core as result of shear forces.

To avoid the presence of this delamination phenomenon, it is intended to get a joint as consistent as possible between skins and core in order to reach a better forces distribution between the "sandwich" components without the "sandwich" stiffness being affected. The solution to this problem generally is to employ hardened adhesive layers, placed between skins and core, that confer higher mechanical properties to the joint between both elements.

Another kind of solution in order to increase the "sandwich" resistance to the delamination phenomenon is the introduction of some laminae of less stiffness in the skins laminates. This alternative will make to increase the" sandwich" tendency to delamination because it will make easier the sliding between the less stiff laminae and the more stiff ones, but the fracture strength due to this phenomenon will increase. Anyway, the shear properties of the skins, in which is related to 
de cortadura de las pieles del "sandwich", en lo que a rigidez se refiere, se verán reducidas.

\subsection{Concentraciones de tensiones en agujeros y uniones atornilladas}

La presencia de un agujero o unión atornillada siempre produce una concentración de tensiones en su entorno debido a que se está introduciendo una discontinuidad en el material. Este tipo de problema se presenta de forma más patente en paneles "sandwich" con núcleos del tipo "honeycomb" (nido de abeja) los cuales son de por sí elementos discontinuos. La solución suele consistir en inyectar localmente, en torno del agujero o unión, espumas sintéticas que reduzcan las concentraciones de tensiones y por consiguiente las posibilidades de que se dañe la estructura. Sin embargo, cualquier modificación que se realice en la estructura conlleva una penalización en lo que a costes adicionales de producción se refiere.

\subsection{Resistencia al fuego}

Las últimas tendencias en el estudio de nuevas espumas sintéticas para ser utilizadas como núcleos de paneles "sandwich" han apuntado hacia la resistencia a los efectos del fuego así como a la reducción de los gases emitidos durante una posible combustión.

Las soluciones incluyen la adición de agentes retardantes y el desarrollo de nuevas espumas sintéticas que desprendan durante su combustión humos de baja toxicidad. La penalización que se paga en este caso es el empobrecimiento de las propiedades de compresión y cortadura de estas espumas. Esta penalización en las propiedades mecánicas de las espumas obliga a incrementar la densidad de las mismas para obtener unos valores de las propiedades que sean aceptables y entonces la penalización se traduzca en un aumento de peso de la estructura, con lo cual la utilización de paneles "sandwich" podría no ser tan interesante.

\section{TEJIDOS TRIDIMENSIONALES PARA SU APLICACIÓN AL DESARROLLO DE ESTRUCTURAS TIPO "SANDWICH"}

\subsection{Introducción}

La problemática común existente en el proceso de diseño de estructuras con paneles "sandwich" convencionales y el continuo estudio de nuevas posibles modificaciones que se pudiesen introducir de forma factible en los mismos ha originado el nacimiento de una nueva técnica para la elaboración de paneles "sandwich" a partir de tejidos tridimensionales que stiffness, would be reduced.

\subsection{Stresses concentrations around holes and bolted joints}

The presence of a hole or a bolted joint always produces a stress concentration around it due to the discontinuity which is introduced in the material. This kind of problem is more evidently present in "sandwich" panels with "honeycomb" cores which are themselves discontinuous elements. The solution usually consists of locally injecting, around the hole or joint, synthetic foams that decrease the stresses concentrations as so the possibility of damage in the structure. Anyway, any modification being carried out in the structure implies an additional manufacturing cost penalty.

\subsection{Fire resistance}

The last tendencies in the researching of new synthetic foams to be employed as core in "sandwich" panels have been focused both on the resistance to the fire effects and the reduction of the gases being emitted during a hypothetic combustion.

The solutions include the addition of delaying agents as well as the development of new synthetic foams that emit low toxicity smoke during combustion. The penalty in this case is the lower properties in compression and shearing of these foams. This reduction in the mechanical properties of the foams makes to increase their density to allow the properties with acceptable values; thus, the penalty is traduced to an increasing of the weight structure, that could take the "sandwich" structure to a non very competitive position.

\section{THREE DIMENSIONAL FABRICS FOR THEIR APPLICATION TO THE DEVELOPMENT OF "SANDWICH" STRUCTURES}

\subsection{Introduction}

The common problematic that exists in the designing of structures with conventional "sandwich" panels and the continuous research on new modifications that could be successfully introduced in them have originated the birth of a new technique of developing "sandwich" panels from three dimensional fabrics; this technique seems to be candidate to the reduction of that 
parece ser candidata, si no a la eliminación, sí a la reducción en gran medida de dicha problemática. El hecho de que esta nueva técnica se presente tan prometedora ha originado el que, durante los últimos años, se haya estado trabajando incesantemente en Europa en el desarrollo de este nuevo tipo de estructura sandwich realizada a partir de tejidos tridimensionales.

Aunque el nuevo tipo de "sandwich" es ya totalmente operativo desde el punto de vista industrial, algunas compañias europeas dedicadas a la tejeduría, universidades y empresas privadas han visto en ella un gran potencial, tanto desde el punto de vista de su interés tecnológico como del económico, y están concentrando y aunando esfuerzos de cara a mejorar los procesos de fabricación para distintos materiales de tejido, desarrollar nuevas resinas que se adapten mejor a este tipo de tejido, optimizar y agilizar los métodos de cálculo y diseño, y ampliar el campo de aplicaciones industriales donde la reducción de costes y pesos de una estructura sean primordiales.

A continuación se verán algunos aspectos sobre la elaboración de este nuevo tipo de panel "sandwich" así como las ventajas que puede suponer su utilización con respecto a los paneles "sandwich" convencionales.

\subsection{Tejidos-3D para estructuras "sandwich"}

Como se ha dicho anteriormente, esta nueva técnica de elaboración de paneles "sandwich" se lleva a cabo a partir de tejidos tridimensionales.

Para aclarar someramente lo que es un tejido tridimensional, que a partir de ahora denominaremos más concisamente como tejido-3D, diremos que es todo tipo de tejido en el que podemos encontrar fibras orientadas en las tres direcciones del espacio. Estas fibras se impregnan con las resinas que se estimen oportunas para cada aplicación, se curan y de este proceso se obtiene un considerable aporte en lo que a las propiedades mecánicas del material compuesto resultante se refiere.

El nuevo tipo de tejido-3D utilizado para la elaboración de paneles "sandwich" del que estamos hablando se compone básicamente de dos tejidos convencionales, que desempeñarán el papel de pieles de dicho "sandwich", interconectados entre sí por medio de manojos de fibras, llamadas "piles,"que viajan de forma continua de uno de los tejidos al otro (Fig. 1). Estos manojos de fibras transversales son los que confieren al tejido la característica de tridimensionalidad.

La gran ventaja de este tipo de tejido es que los "piles" pertenecen en realidad a los dos tejidos. Es decir, un "pile" es un conjunto de fibras, que pertenece a uno de problematic. The fact of this new technique appearing as being so promising has give rise to an incessant work on it in Europe during the last years.

Even the new "sandwich" typology is already fully operative from an industrial point of view, some European companies which are dedicated to the weaving, universities and private companies have seen on it a huge potential from both a technological and an economic point of view. These companies and universities are concentrating and combining their efforts in order to improve the manufacturing processes for different material for weaving, to develop new resins for this new fabric, to optimise and make agile the calculus and design methods, and to extend the range of industrial applications in which the cost and weight reduction of a structure will be primordial.

Next some aspects on the momufacturing of this new "sandwich" panel typology, as well as the advantages of using it instead of conventional "sandwich" panels, will be shown.

\subsection{D-Fabrics for "sandwich" structures}

As it has been said before. this new technique of manufacturing "sandwich" panels is carried out from three dimensional fabrics:

In order to briefly clarify what a three dimensional fabric (3I)-fabric from now) is, it could be said that is any kind of fabric in which it is possible to find fibres oriented in any of three directions of the space. These fibres are impregnated with the resins which are considered as the best depending on the application: after they are cured, being obtained then a considerable contribution in which is referred to mechanical properties of the resultant composite material.

The new type of 3D-fabric which is used for manufacturing "sandwich" panels we are talking about, it consists basically of two conventional fabrics, that will act as skins of the "sandwich", which are interconnected between them by means of fibre yarns. called "piles", that goes continually form one fabric to the other (Fig. l). These transversal fibre yarns are the ones that confer to the fabric the characteristic of three dimensionality.

The big advantage of this kind of fabric is that the "piles" belong in fact to the two fabrics. This is, a "pile" is a set of fibres that belongs to one of the fabric and that 


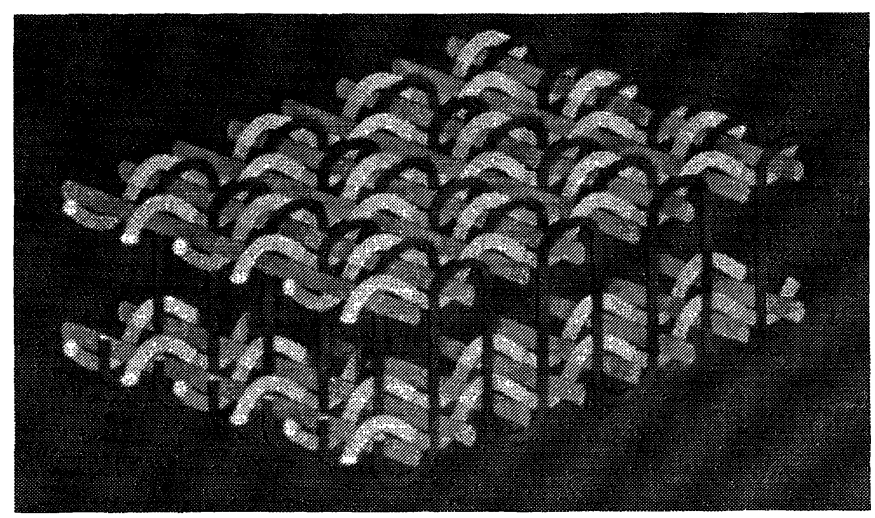

Fig. 1.- Esquema de un tejido-3D.

Fig. 1.-Scheme of a 3D-fabric.

los tejidos y que durante el proceso de tejeduría se desvía para que pase a formar parte del otro y que además, posteriormente, vuelve al tejido del que partió.

Adicionalmente se tiene también la ventaja de que todo el proceso de tejeduría de los dos tejidos convencionales y así como el control de los "piles" que los interconectan se realiza en un único paso.

El desarrollo de esta técnica de elaboración en un solo paso de tejidos-3D ha supuesto el que se puedan reducir de forma considerable los costes de elaboración de estructuras "sandwich". Además el proceso es sumamente versátil, ya que es posible fabricar estos tejidos utilizando prácticamente cualquier tipo de fibra convencional (incluso carbono); se puede controlar la longitud de los "piles" (en la actualidad, y aproximadamente, de 4 a $60 \mathrm{~mm}$ según materiales y fabricantes) y adicionalmente se puede controlar la densidad de "piles" por metro cuadrado.

Todo lo expuesto nos permite deducir de inmediato de que para aquellas aplicaciones en las que se requiera una gran inercia a flexión bastará con acudir a longitudes de "pile" grandes y si, por el contrario, lo que se busca es un buen comportamiento ante esfuerzos cortantes, esfuerzos de compresión o cargas de impacto, se procurará incrementar la densidad de "piles" por metro cuadrado.

La posibilidad de introducir como variables del proceso de fabricación la longitud de los "piles" así como la densidad de los mismos, hace que los tejidos-3D sean candidatos a ser utilizados como alternativa a los paneles "sandwich" convencionales en prácticamente todos los campos. during the weaving process is deflected to pass to belong to the other and also, subsequently, comes back to the first fabric.

Additionally, there is also an advantage of weaving in an only step the two conventional fabrics and the "piles" that interconnect them.

The development of this technique of manufacturing in only one step 3D-fabrics has allowed a considerable reduction of the manufacturing costs of "sandwich" structures. As well, the process is very flexible, because it is possible to manufacture these fabrics with almost any kind of conventional fibres (even carbon); it is possible to control the "piles" length (nowadays, in a range from 4 to $60 \mathrm{~mm}$., depending on materials and manufacturers) and additionally it is possible to control the density of "piles" per square meter.

All that has been priory stated allows us to immediately infer that for those applications in which it is required a high flexural inertia it will be enough to go for high lengths of "pile" and if, in the other way, a good behaviour is needed under shear forces, compressive forces or impact loads, it will be attempted to increase the density of "piles" by square meter.

The chance of introducing as variables of the manufacturing process the length of the "piles" as well as their density, makes the 3D-fabrics to be considered as an alternative to the conventional "sandwich" panels in almost all their applications. 


\subsection{Limitaciones de los tejidos-3D}

Los materiales compuestos en general, y en concreto los tejidos-3D, carecen por sí mismos de todo tipo de estabilidad estructural, al igual que cualquier otro tejido sin impregnar ya que, como se ha explicado anteriormente, están constituidos únicamente por fibras entretejidas.

Para conferir al tejido la estabilidad y propiedades mecánicas requeridas, es necesario que tras el proceso de elaboración de los tejidos-3D estos sean impregnados con las resinas adecuadas, y posteriormente curados (Figs. 2 y 3). Esta necesidad ha hecho que se produzca un doble proceso de adaptación entre fabricantes de tejidos y de resinas, ya que los primeros buscan que sus tejidos tengan unas densidades de "piles" que permitan una fácil impregnación por parte de las resinas existentes en el mercado mientras que los segundos buscan el poder ofrecer resinas de nuevo desarrollo que se adapten mejor a los tejidos fabricados.

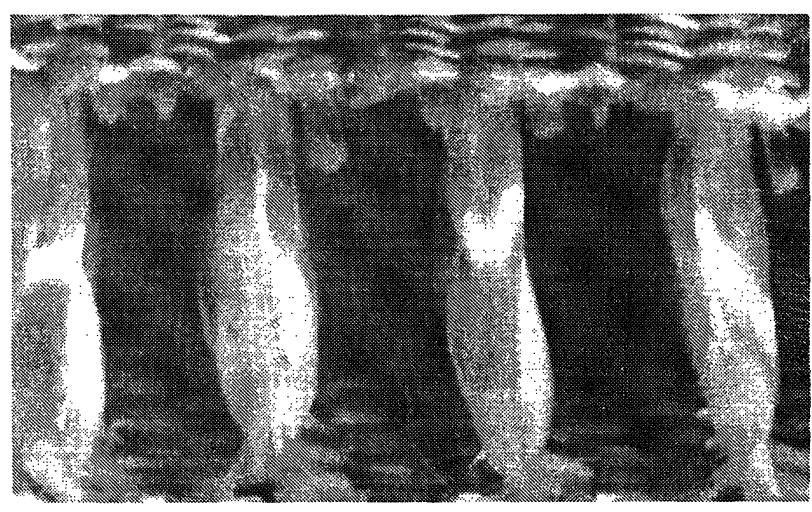

Fig. 2.- Detalle de tejido-3D seco. Fig. 2.- Detail of dry 3I-fabric.

Pero pese a la gran versatilidad de fabricación que ofrecen los tejidos-3D, la necesidad de estandarizar productos, de cara a poder reducir los costes de fabricación y así poder ofrecer un producto competitivo en precio, ha llevado a que los fabricantes de este tipo de tejidos se hayan visto obligados a limitar de alguna forma la oferta de longitudes de "piles" así como sus densidades por metro cuadrado. Este proceso de estandarización supone que si se quiere trabajar con tejidos-3D, no se podrá seleccionar libremente el tejido que por requisitos de diseño de la estructura sea el óptimo, sino que se tendrá que acudir a los catálogos que suministren los fabricantes y buscar aquél que más se ajuste a los requerimientos de diseño.

\subsection{D-Fabric limitations}

The composite materials, and concretely the 3D-fabrics, lack themselves of any kind of structural stability, as any other fabric without having been impregnated because as, it has been priory explained, they simply consist of woven fibres.

To confer to the fabric the required stability and mechanical properties, it is necessary after the manufacturing process of the 3D-fabrics to impregnate them with the appropriated resins. After that, the impregnated fabrics are cured (Figs. 2 and 3). This need has conduced to a double process of adaptation between fabric and resins manufacturers, the firts ones try to get an appropriated density of "piles" to allow an easy impregnation process.

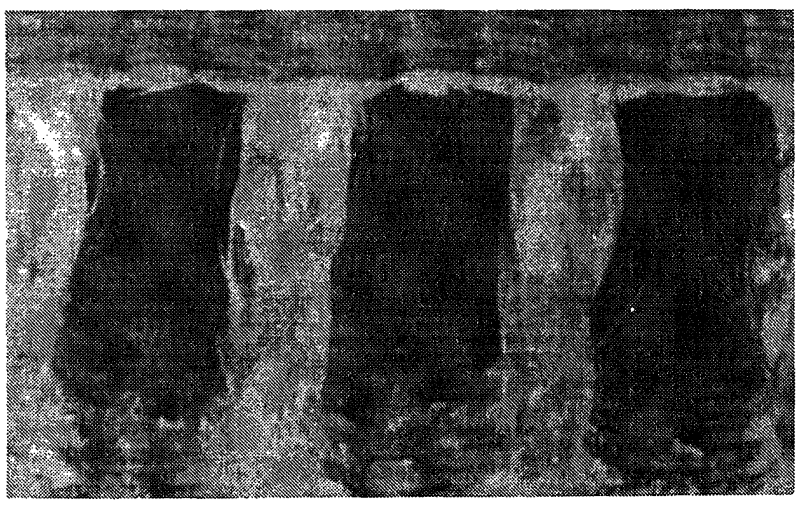

Fig. 3.- Detalle de tejido-3D impregnado. Fig. 3.- Detail of impregnated 3D-fabric.

But even considering the high manufacturing versatility that the 3D-fabrics offer, the need of standard products, in order to cut out the manufacturing costs and so making possible to get a product which is competitive in cost, has led the manufacturers of this kind of fabrics up to limit somehow the offer of "piles" lengths as well as their densities per square meter. This standardisation process implies that if it is decide to work with $3 D$-fabrics, it is not possible to freely select the optimum fabric for the structural requirements, but it is necessary to use the manufacturers catalogues to find the fabric that better fits the design requirements. 
Hoy en día, a la hora de seleccionar un tejido-3D, las limitaciones con las que más habitualmente nos encontraremos serán las siguientes:

- Tipo de material. Actualmente la producción a nivel industrial de estos tejidos se limita casi exclusivamente a la fibra de vidrio.

. Espesor de pieles. Del orden de 0,35 mm después del proceso de impregnación y curado de la resina.

. Longitud de "piles". Generalmente se encontrará una gama de unas seis $u$ ocho longitudes diferentes de "pile", abarcando un rango de un espesor total nominal mínimo de unos $4 \mathrm{~mm}$ hasta un máximo de unos 60 $\mathrm{mm}$.

. Densidad de "piles". Normalmente se encontrarán dos o tres diferentes densidades de "piles" para cada espesor nominal de tejido. Cada fabricante procura elaborar los tejidos-3D con una densidad de "piles" que garantice una buena impregnación de las resinas existentes en el mercado.

Todas las limitaciones que se han citado obligarán al diseñador a realizar algunas modificaciones sobre los tejidos para obtener las propiedades mecánicas que busca.

\subsection{Modificaciones de los tejidos-3D}

De entre las modificaciones que más frecuentemente se llevan a cabo sobre los tejidos-3D podemos destacar las siguientes:

- Limitar el grado de estiramiento de los "piles". Durante el proceso de curado se evita que los "piles" adquieran una disposición perpendicular a las pieles para que, de esta forma, el espesor del panel después del proceso de curado sea ligeramente menor que el espesor nominal indicado. Esto permitirá que si no se dispone del tejido cuyo espesor nominal (el correspondiente a un estiramiento del $100 \%$ ) sea el deseado, se pueda utilizar el tejido de espesor nominal inmediatamente superior. Este proceso es lo que se conoce como control del "stretching".

- Disposición de pieles adicionales. Cuando las propiedades mecánicas de las pieles del tejido-3D sean insuficientes para satisfacer los requerimientos de la estructura se podrán disponer tejidos-2D adicionales que confieran una mayor rigidez a flexión, o a compresión en el plano, de los paneles "sandwich" fabricados. Esta modificación puede ser requerida también para prevenir posibles fenómenos de pandeo del panel "sandwich".
Nowadays, at the time of selecting a $3 D$-fabric, the more usual limitations that can be found are:

. Kind of material. At present, the industrial production of these fabrics is almost exclusively limited to the glass fibre.

\section{. Skin thickness. Around $0.35 \mathrm{~mm}$ after the} impregnation and curation process.

. Length of "piles". Generally, there will be available a series of six or eight different lengths in a range of a nominal total thickness from 4 up to $60 \mathrm{~mm}$.

. "Piles" density. Usually, two or three different piles densities will be available foreach nominal thickness of fabric. Each manufacturer should try to manufacture the fabrics with densities that guarantee a good impregnation with the commercially available resins.

These limitations force the designer to make some modifications over the fabrics to get the desired mechanical properties.

\subsection{D-Fabrics modifications}

Among the more frequently modifications that are carried out in the 3D-fabrics the next ones can be highlighted:

. Limiting the degree of stretching of the "piles" During the process of curing it is avoided that the "piles" reach a perpendicular position to the skins. so the thickness after the curing process is lightly less than the nominal one. This allows, when the required thickness is not available as a nominal one $1100 \%$ stretched), to use the immediately higher one. This process is known as "stretching" control.

. Disposition of additional skins. When the mechanical properties of the skins of the 31)-fabric are insufficient to fulfil the structural requirements additional conventional 2I)-fabrics can be used to confer higher in-plane flexural and compression stiffnesses to the "sandwich" panel. This modification can be also required to prevent buckling of the" sandwich" structure. 
- Inyección de espumas. Con el objeto mejorar las propiedades del panel "sandwich" ante esfuerzos de compresión plana o cortadura, se puede proceder a la inyección de espumas sintéticas en el interior de tejido-3D. Además, y en el caso concreto de compresión plana, aunque por consideraciones de rigidez no sea necesaria la presencia de una espuma, ésta puede ser útil para evitar el pandeo de los "piles".

No obstante hay que reseñar el hecho de que un tejido-3D que hoy requiera alguna de las modificaciones citadas pueda estar comercialmente disponible mañana sin requerir esas modificaciones, debido a que ésta es una técnica que está en fase de rápida evolución.

\subsection{Los tejidos-3D ante los problemas clásicos de los paneles "sandwich"}

\subsubsection{Introducción}

Anteriormente se citó el hecho de que el diseño de estructuras mediante la utilización de paneles sandwich convencionales nos enfrentaba ante una serie de problemas comunes y bien conocidos. En concreto se habló del problema de la delaminación, el fenómeno de las concentraciones de tensiones que se producen en el entorno de agujeros y uniones atornilladas y el problema de la resistencia al fuego.

A continuación se dará una visión de las ventajas que reportan los tejidos-3D ante estos problemas.

\subsubsection{Delaminación}

Como ya se comentó anteriormente, las tendencias actuales para buscar una solución al problema de la delaminación se inclinaban por la búsqueda de nuevos adhesivos que mejorasen las propiedades mecánicas de la conexión entre las pieles y el núcleo.

Con el desarrollo de los tejidos-3D para su aplicación a la elaboración de paneles "sandwich", el elemento adhesivo entre pieles y núcleo desaparece (recordemos que son los piles los que las unen) y por lo tanto el problema de la delaminación queda eliminado, o por lo menos limitado, a aquéllos niveles tensionales a los que pueda ser llevado el material utilizado.

\subsubsection{Concentraciones de tensiones en agujeros y uniones atornilladas}

Aunque los tejidos-3D, al igual que los paneles tipo "honeycomb" (o nido de abeja), presentan
. Injection of foams. With the object of improving the properties of the "sandwich" panel under plane compression or shear, the injection of synthetic foams inside the 3D-fabric can be carried out. Also, and specifically under plane compression, even stiffness considerations can not make necessary the use of foam, this can be useful to prevent the buckling of the "piles".

Even though, it must be remarked the fact that maybe a 3D-fabric that today needs some of those modifications it could be commercially available tomorrow without requiring to perform the modifications due to the fact that this is a technique in a quick development state.

\subsection{D-Fabrics and classical "sandwich" drawbacks}

\subsubsection{Introduction}

When designing structures by using classical sandwich panels, some classical and well known problems do appear. As an example, delamination, stresses concentrations around holes and bolted joints and fire resistance can be stated.

Next, advantages of using 3D-fabrics to avoid these problems will be reported.

\subsubsection{Delamination}

As previously said, current research to look for solutions to avoid delamination focuses on looking for new structural adhesives improving mechanical properties of skin-to-core connections.

Development of 3D-fabrics to manufacture "sandwich" panels allows not to use adhesives between skin and core (remember that the piles are connecting skin to core) and delamination problems are non-existent or at least limited to the maximum allowable stresses.

\subsubsection{Stresses concentrations around holes and bolted joints}

Although 3D-fabrics present discontinuities in the hollow structure, injection of foam is possible 
discontinuidades en su interior, la inyección de espumas localmente no supone un gran problema, dado que éstas pueden fluir libremente por entre los "piles".

\subsubsection{Resistencia al fuego}

Para los tejidos-3D el problema de la resistencia al fuego se debe considerar en dos situaciones distintas.

La primera de ellas es el caso de que se estén utilizando paneles "sandwich" realizados con tejidos-3D en los que no se haya inyectado espuma alguna.

En este caso el posible desprendimiento de humos tóxicos por parte de la espuma deja de ser un problema y por lo tanto las líneas de trabajo se centran en mejorar las propiedades ignífugas de las materias primas utilizadas.

La otra posible situación es la de estar utilizando paneles "sandwich" realizados con tejidos-3D en los que se haya inyectado alguna espuma sintética.

En este caso se comparte el problema con los paneles "sandwich" convencionales y el trabajo se orienta hacia mejorar la resistencia al fuego de las espumas sintéticas. Como se citó anteriormente, las líneas de trabajo para reducir este problema apuntan hacia la adición de agentes retardantes así como el desarrollo de nuevas espumas que desprendan durante su combustión humos de baja toxicidad. No obstante, la presencia de los piles en el interior del núcleo haría que el volumen de espuma utilizado para la fabricación del panel "sandwich" elaborado con tejidos-3D fuese menor que el volumen de espuma utilizado para elaborar un panel "sandwich" convencional de idéntica geometría.

La gran ventaja aportada por los tejidos-3D en el aspecto de la resistencia al fuego es que los paneles "sandwich" elaborados con esta técnica, ante una eventual pérdida de la espuma, pueden todavía conservar gran parte de su integridad estructural gracias a la presencia de los "piles".

\subsection{Algunas conclusiones sobre la utilización de los tejidos-3D para el diseño de estructuras}

Algunos autores comentan que la utilización de paneles "sandwich" en el diseño de estructuras debe ser considerada cuando se mejoran, por lo menos, dos de todo el conjunto de características que pueda poseer cualquier otra alternativa para realizar ese mismo diseño. Es decir, se podría decir que un panel "sandwich" sería interesante si, por ejemplo, se reduce peso y se facilita el reciclado de materiales, o si se reduce peso y costes de because the foam can flow among the "piles" with no restrictions.

\subsubsection{Fire resistance}

For 3D-fabrics, fire resistance should be considered in two different ways:

When using unfoamed "sandwich" panels made of 3D-fabrics.

Because there is no foam in the core, toxic smoke be non-existent. Research focuses on improving fire resistance for the raw materials used for manufacturing the 3D-fabrics.

When using foamed "sandwich" panels made of 3D-fabrics.

As for classical "sandwich" panels, toxic smoke will appear and research focuses on improving fire resistance for synthetic toams. Anyway, the core of a "sandwich" panel made of 3D-fabrics will be composed of piles and foam. Then, for identical geometry, foam content for a "sandwich 2panel made of 3D-fabrics will be lower than foam content for a classical sandwich panel.

Regarding fire resistance, the great advantage reported by $3 D$-fabrics is due to the fact that when the foam is lost because of the fire, the "piles" are still keeping their structural properties intact.

\subsection{Some conclusions about using 3D-fabrics for structures design}

Some authors state that using sandwich panels for structures design is useful when at least two properties of the structure are improved as a direct consequence of using "sandwich" panels. That is to say, "sandwich" panels should be considered if, for instance, it is possible to save weight and recycling is easier, or it is possible to save weight and manufacturing costs are 
producción, o cualquier otra combinación de al menos dos mejoras en el diseño.

Ante este planteamiento, los tejidos-3D configurados como paneles "sandwich" pueden llegar a mejorar, según se ha visto en el apartado, hasta tres características, no ya de un diseño realizado con otros tipos de materiales sino de diseños realizados con paneles "sandwich" a los que se les supone que están mejorando de antemano otras dos características de otras alternativas de diseño.

Todas estas peculiaridades hacer suponer que los tejidos-3D utilizados para la elaboración de paneles "sandwich" nunca deberían empeorar un diseño realizado con paneles "sandwich" convencionales.

\section{PROCESOS PARA LA FABRICACIÓN DE PANELES "SANDWICH" CONFIGURADOS A PARTIR DE TEJIDOS-3D.}

\subsection{Fabricación manual}

Este proceso consiste en impregnar manualmente el tejido-3D seco con la resina que se haya determinado como idónea para la aplicación a la que vaya destinado el panel "sandwich" resultante. Durante el proceso de curado se produce el estiramiento de los "piles" que conectan los tejidos- $2 \mathrm{D}$.

De entre las ventajas de este tipo de proceso podemos destacar el hecho de que puedan ser fabricados paneles "sandwich" curvos sin más restricción que la de no forzar en el molde grandes curvaturas que impidan un buen estiramiento de fibras.

Por otra parte este proceso tiene el inconveniente de que como el fenómeno de estiramiento de fibras se produce por sí solo y sin ningún tipo de control, no se garantiza que se consiga un estiramiento total de los manojos de fibras que conectan las pieles. Por este motivo cuando se haga referencia a este tipo de "sandwich-3D" habrá que hablar de la referencia de tejido-3D utilizada y especificar el grado de estiramiento (o "stretching") de "piles" conseguido. Además el acabado del panel puede ofrecer variaciones significativas de espesor en distintas zonas del mismo.

El método manual suele ser utilizado para producir paneles "sandwich" de no muy grandes dimensiones y en series más bien reducidas. Así mismo, este método exige también que el panel vaya destinado a prestar servicio como elemento estructural en aplicaciones en las que el acabado superficial o las tolerancias de espesores no se vean sometidos a controles rigurosos. lower, or any other couple of improvements can be achieved.

"Sandwich" panels made of 3D-fabrics can improve up to three characteristics for previous designs made of classical "sandwich" panels in which these classical "sandwich" panels are supposed to be already improving at least two characteristics when comparing to a design where "sandwich" panels are not used.

As a conclusion, "sandwich" panels made of $3 D$-fabrics never should decrease the quality of a design where classical "sandwich" panels are used.

\section{MANUFACTURING METHODS FOR ELABORATING "SANDWICH" PANELS MADE OF 3D-FABRICS}

\subsection{Hand manufacturing}

In this process, the dry 3D-fabric is impregnated with the amount of resin required by the application where the resultant "sandwich" panels will be used. The stretching of the "piles" used to connect the 2D-fabrics occurs while the resin is curing.

As one of the most important advantages of this method, it is possible to manufacture curved "sandwich" panels. The only restriction that will apply, is not to impose large curvatures that will prevent a good stretching of the fibre.

On the other hand, this method will prevent from meeting very strict dimensional requirements as the piles stretch by themselves with no control. Then, there is not guarantee for reaching the full stretching of the pile yarns. This is the reason why, when making reference to this kind of "3D-sandwich", it will be necessary to specify the 3D-fabric reference used as well as the degree of "stretching" reached during the process. In addition, the finishing of the panel may vary for different zones on the same panel.

This method is usually applied for manufacturing small "sandwich" panels and short number of units.

Likewise, this method also requires the panel to give service as structural element in applications in which the surface finished or widths tolerances are not subjected to strict controls. 
Algunas de las aplicaciones en las que este proceso se está aplicando hoy en día son asientos para aviones ultraligeros, paneles separadores para oficinas, baldosas para suelos de autobuses, barcos y aviones, bloques sanitarios, ...

En general podemos hablar de todas aquellas aplicaciones que posteriormente vayan a ser sometidas a cualquier tipo de recubrimiento superficial como pueden ser alfombras, moquetas, pinturas, etc.

\subsection{Fabricación por vacío}

La elaboración de paneles "sandwich" tridimensionales mediante la aplicación de vacío permite que el acabado superficial sea de alta calidad y que el estiramiento de los "piles" pueda llegar a ser del cien por cien, ya que a diferencia del proceso manual, en este caso el estiramiento de los "piles" se ve forzado por la depresión que se aplica sobre el tejido. El esquema de elaboración de un panel "sandwich" a partir de un tejido-3D se muestra en la Fig. 4.

El proceso consiste básicamente en disponer sobre una superficie horizontal el tejido-3D impregnado con la resina. Inmediatamente después, este tejido se cubre con una bolsa que lo cierra herméticamente y posteriormente se le acopla el dispositivo de vacío.

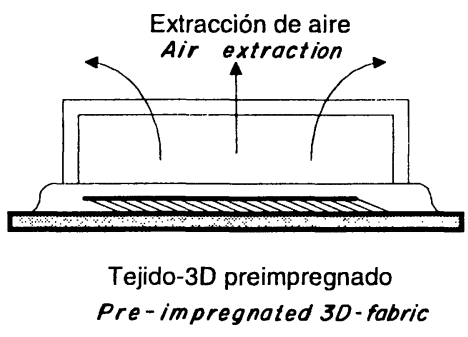

Some of the classical applications where this manufacturing process is used are: ultralight aircraft, plates for buses and ships floors, sanitary blocks, ...

In general, this process is suitable in all applications later subjected to any type of surface covering as carpets, moquettes, paints etc.

\subsection{Vacuum method}

When manufacturing 3D -"sandwich" panels by applying the vacuum method it is possible to obtain very high quality finishing together with degrees of stretching near to $100 \%$. In this case the stretching of the piles is imposed by the vacuum applied on the fabric. The scheme for elaborating a "sandwich" panel made of $3 D$-fabrics is shown in Fig. 4.

When using this process, a 3D -fabric impregnated with resin is disposed on a horizontal surface. The fabric is covered with a plastic bag and the vacuum device is attached.

Fig. 4.- Elaboración de paneles "sandwich"-3D por el método de vacío.

Fig. 4.- 3D-"sandwich" panels manufacturing. Vacuum method.

Cuando los "piles" están estirados se espera hasta que la resina endurezca y posteriormente se retira el dispositivo de vacío.

En este proceso de fabricación las dimensiones de los paneles que se vayan a fabricar se verán limitadas por las características de la maquinaria utilizada y el estiramiento de los "piles" se podrá ajustar a las necesidades de la aplicación en concreto, ya que mediante el control de vacío ejercido sobre el tejido se podrá controlar el porcentaje de estiramiento.

Este proceso es muy indicado para producir paneles "sandwich" en grandes series con un acabado superficial de alta calidad y estricto control dimensional.
As soon as the "piles" are stretched, because of the air extraction, and the resin is cured, the vacuum device is removed.

When applying this manufacturing process, the dimensions of the panels will find as a limitation, the characteristics of the machinery used. It will be possible to control the degree of stretching by controlling the vacuum level applied to the 3I-fabric.

This process is suitable for manufacturing large number of "sandwich" panels, with high quality finishing and very strict dimensional requirements. 


\section{ALGUNAS DE LAS APLICACIONES DE LOS PANELES "SANDWICH"} CONFIGURADOS A PARTIR DE TEJIDOS$3 D$.

Los tejidos-3D utilizados para la elaboración de paneles "sandwich" han probado ser alternativas de gran éxito en los siguientes campos de aplicación:

- Construcción: Por su bajo peso y propiedades de aislamiento térmico.

- Automoción: Por su bajo peso y alta resistencia frente a impactos.

- Tanques de almacenamiento: Por su rigidez a flexión y posibilidad de ser utilizados como cámara de detección de escapes.

- Aviones ultraligeros: Por su bajo peso y alta resistencia frente a la delaminación.

Centrándonos en el campo de la construcción algunas de las aplicaciones más usuales son: bloques sanitarios integrales, paneles separadores, probadores para tiendas, "stands" para exposiciones y congresos, domos para radares, ... Una aplicación de este material se ha llevado a cabo en la reparación de unas lamas del vestíbulo principal del Instituto Eduardo Torroja de Ciencias de la Construcción (CSIC) de Madrid. La Fig. 5 muestra el ventanal citado.

\section{SOME PRACTICAL APPLICATIONS OF "SANDWICH" PANELS MADE OF 3D - FABRICS}

3D-fabrics used for "sandwich" panels manufucturing have probed to be useful in the following application fields:

. Building construction: Low weight and good thermal insulation.

. Automotive industry: Low weight and high impact resistance.

. Tanks for liquids: High flexural rigidity and suitable to be used as escape detection.

\section{. Ultralight aircraft: Low weight and high delamination strength.}

Regarding the field of building construction, some of the most important applications are: integral sanitary blocks, fitting rooms, radar domes, booths for exhibits, ... This material was used to repair the boards on the large window in the main hall of the Eduardo T'orroja Institute for Building Sciences (CSIC) Madrid. The window is shown in Fig. 5.

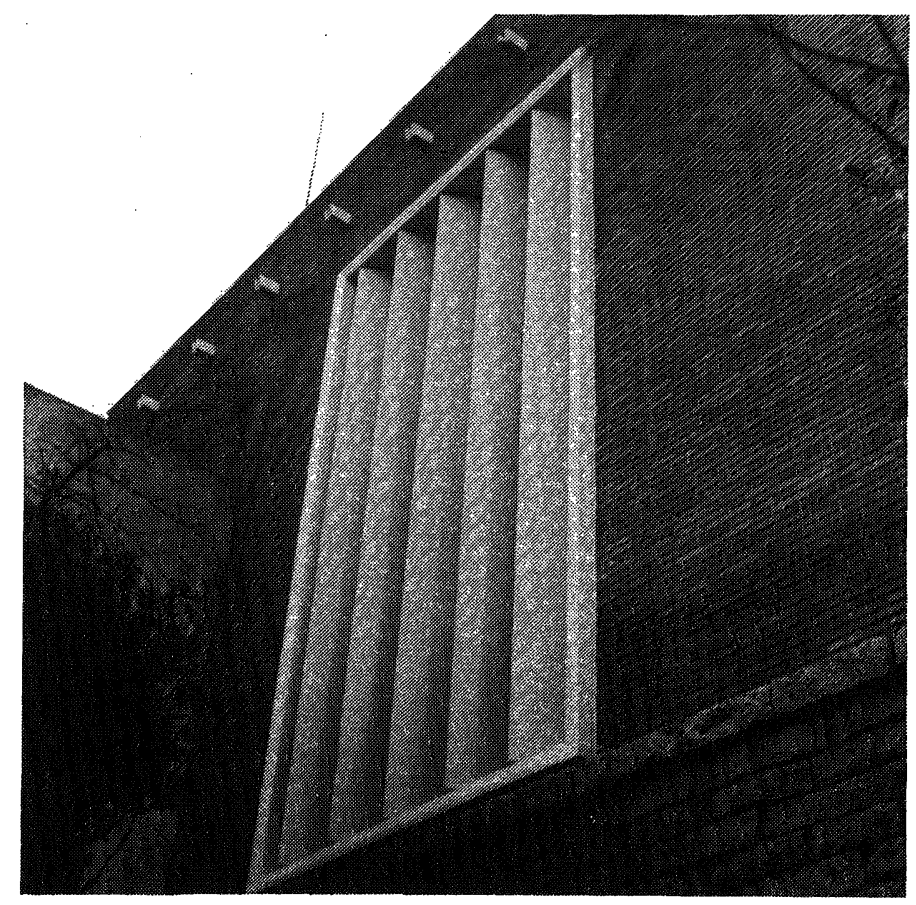

Fig. 5.- Ventanal del vestíbulo principal del IETCC

Hig. S.- Window in the main hall of the IETCC. 


\section{BIBLIOGRAFÍA}

(1) ANTEQUERA, P., JIMÉNEZ, L., MIRAVETE, A.: "Cálculo y Diseño de Estructuras de Materiales Compuestos de Fibra de Vidrio", Secretariado de Publicaciones de la Universidad de Zaragoza, 1993.

(2) BERTHELOT, J. M.: “Matériaux Composites, Comportement Mécanique et Analyse des Structures", Masson, 1992.

(3) CAPRINO, G., TETI, R.: "Sandwich Structures. Handbook", Il Prato, 1989.

(4) CHOU, T., KO, F.: "Textile Structural Composites", Elsevier, 1989.

(5) GAY, D.: “Matériaux Composites", HERMÈS, 1991.

(6) IVENS, J., VERPOEST, I., VANDERVLEUTEN, P.: "Improving the Skin Peel Strength of Sandwich Panels by Using 3DFabrics", Proceedings of the ECCM-5. Editors F.L. Mathews et al, Pergamon Press, London, 1987

(7) VAN DER VEEN, R.R.: "Test Report of Mechanical Properties of Parabeam Three Dimensional Woven Glass Fabric Panels", Test Report 86 Series, Parabeam Helmond, Enero 1993.

(8) VERBRUGGE, K., IVENS, I., VERPOEST, I., VANDERVLEUTEN, P.: "Foamed 3D-Fabric Sandwich Structures", Proceedings European SAMPE, A. Kwakernaak, L. Van Arkel, Ed., Maastricht, 1991.

(9) VERPOEST, I., KO, F., WULFHORST, B., BEUKERS, A.: "Seminair on New Textiles for Composites", Leuven (Belgium), 1991.

(10) VERPOEST, I., WEVERS, M., DE MEESTER, P., DECLERRQ, P.: “2.5D- and 3D-Fabrics for Delamination Resistant Composite Laminates and Sandwich Structures”, Sampe Jornal, vol. 25, no 3, pp. 51-56, May/June 1989.

(11) SWINKELS, K.: "Three Dimensional Woven Fabrics as Reinforcements in Composites", Proceedings ICCM-9, Madrid, 1993.

\section{publicación del IETCC/CSIC}

\section{INSPECCION DE OBRAS DAÑADAS POR CORROSION DE ARMADURAS}

El presente Manual va dirigido principalmente a técnicos especializados y laboratorios que tienen que intervenir en el dictamen de la situación de deterioro de estructuras de hormigón armado dañadas por corrosión de armaduras.

Comienza con un resumen recordatorio de los factores principales a los que se pueden deber los daños prematuros por corrosión de armaduras, para seguir con algunas indicaciones de cómo se deben realizar las inspecciones, y de los ensayos y la metodología que se recomienda realizar para poder dictaminar con precisión las causas de daño.

A continuación se hacen una serie de comentarios sobre la vida residual de estructuras dañadas, sobre el riesgo de corrosión futura, el seguimiento necesario de una estructura reparada y una breve enumeración de métodos de reparación y consideraciones básicas a tener en cuenta en la recomendación de un determinado método. Se aporta una breve relación bibliográfica.

Finalmente se incluyen en forma de ficha la descripción de algunos casos de corrosión de armaduras detectados en nuestro país.

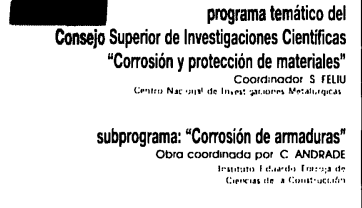

